\title{
Detection of Campylobacter jejuni, Campylobacter coli, and virulence genes in poultry products marketed in Northeastern Brazil
}

\author{
Detecção de Campylobacter jejuni, Campylobacter coli genes de virulência em produtos avícolas \\ comercializados na região Nordeste do Brasil
}

Detección de Campylobacter jejuni y Campylobacter coli y genes de virulencia en productos avícolas comercializados en el Noreste de Brasil

Received: 08/09/2021 | Reviewed: 08/15/2021 | Accept: 08/16/2021 | Published: 08/18/2021

Felipe Pereira de Melo

ORCID: https://orcid.org/0000-0002-0478-0345

Rural Federal University of Pernambuco, Brazil E-mail: phelipe16_2010@hotmail.com

Priscila Oliveira da Silva

ORCID: https://orcid.org/0000-0003-4269-7443

Rural Federal University of Pernambuco, Brazil E-mail: oliveira.priscila60@gmail.com

Saruanna Millena dos Santos Clemente ORCID: https://orcid.org/0000-0002-2528-9416 Rural Federal University of Pernambuco, Brazil E-mail: saruannamillena@ hotmail.com

Renata Pimentel Bandeira de Melo ORCID: https://orcid.org/0000-0001-7162-2745 Rural Federal University of Pernambuco, Brazil E-mail: renatapbm@gmail.com

José Givanildo da Silva

ORCID: https://orcid.org/0000-0001-5565-7980 Rural Federal University of Pernambuco, Brazil E-mail: givanildojgs@gmail.com José Wilton Pinheiro Júnior

ORCID: https://orcid.org/0000-0002-0266-0956 Rural Federal University of Pernambuco, Brazil

E-mail: wilton.pinheiro@ufrpe.br

Belchiolina Beatriz Fonseca

ORCID: https://orcid.org/0000-0001-8485-078X Federal University of Uberlandia, Brazil E-mail: biafonseca@ufu.br Marcelo Mendonça

ORCID: https://orcid.org/0000-0001-7415-457X Federal University of Agreste of Pernambuco, Brazil

E-mail: marcelomendoncavet@gmail.com

Mércia Rodrigues Barros

ORCID: https://orcid.org/0000-0003-3449-9164 Rural Federal University of Pernambuco, Brazil E-mail: mercia.barros@ufrpe.br

\begin{abstract}
In this study, we evaluated the prevalence of Campylobacter jejuni, Campylobcater coli, and virulence genes in fresh, chilled, and frozen chicken carcasses with livers and gizzards sold in public markets and supermarkets. Of the 90 samples analyzed, $C$. jejuni was the most prevalent, with $28.8 \%$ of positive samples, whereas $C$. coli was positive in $15.6 \%$ of samples. In public market samples, $C$. coli had a higher prevalence than $C$. jejuni, with $16.7 \%$ positive samples detected, whereas in supermarket samples, $C$. jejuni was more prevalent (36.7\% positivity). $C$. jejuni was detected in all forms of commercialized carcasses; however, there was a higher prevalence $(43.3 \%)$ in chilled samples than $C$. coli, which was not detected in frozen samples but showed a higher prevalence $(16.7 \%)$ in fresh samples. Both species were detected in different poultry products, with $C$. jejuni being more prevalent $(53.3 \%)$ in liver samples. $C$. coli showed a higher prevalence in samples of meat pieces $(10 \%)$. The presence of five virulence genes related to adherence (Peb1, JlpA, CadF, and CapA) and invasion (CiaB) was also observed in both species.
\end{abstract}

Keywords: Campylobacter; Broiler chickens; Microbiological control; PCR. 


\begin{abstract}
Resumo
Neste estudo, avaliamos a prevalência de Campylobacter jejuni, Campylobacter coli e genes de virulência em carcaças de frangos frescas, resfriadas e congeladas com fígados e moelas comercializadas em mercados públicos e supermercados. Das 90 amostras analisadas, C. jejuni foi a mais prevalente, com 28,8\% das amostras positivas, enquanto $C$. coli foi positiva em $15,6 \%$ das amostras. Nas amostras do mercado público, $C$. coli teve uma prevalência maior do que $C$. jejuni, com $16,7 \%$ de amostras positivas detectadas, enquanto nas amostras de supermercado, $C$. jejuni foi mais prevalente $(36,7 \%$ de positividade). $C$. jejuni foi detectado em todas as formas de carcaças comercializadas; entretanto, houve prevalência maior $(43,3 \%)$ nas amostras resfriadas do que $C$. coli, o que não foi detectado nas amostras congeladas, mas apresentou prevalência maior (16,7\%) nas amostras frescas. Ambas as espécies foram detectadas em produtos avícolas diferentes, com $C$. jejuni sendo mais prevalente $(53,3 \%)$ em amostras de fígado. $C$. coli apresentou maior prevalência em amostras de pedaços de carne (10\%). A presença de cinco genes de virulência relacionados à adesão $(P e b 1, J l p \mathrm{~A}, C a d \mathrm{~F}$ e $C a p \mathrm{~A})$ e invasão $(C i a \mathrm{~B})$ também foi observada em ambas as espécies.
\end{abstract}

Palavras-chave: Campylobacter; Frangos de corte; Controle microbiológico; PCR.

\title{
Resumen
}

En este estudio, evaluamos la prevalencia de Campylobacter jejuni, Campylobacter coli y genes de virulencia en canales de pollos frescos, refrigerados y congelados con hígados y mollejas vendidos en mercados públicos y supermercados. De las 90 muestras analizadas, C. jejuni fue la más prevalente, siendo el 28,8\% de las muestras positivas, mientras que $C$. coli fue positiva en el 15,6\% de las muestras. En muestras del mercado público, $C$. coli tuvo una mayor prevalencia que $C$. jejuni, con un $16,7 \%$ de muestras positivas detectadas, mientras que en muestras de supermercados, $C$. jejuni fue más prevalente (36,7\% de positividad). $C$. jejuni se detectó en todas las formas de canales comercializadas; sin embargo, hubo una mayor prevalencia $(43,3 \%)$ en muestras enfriadas que en $C$. coli, que no se detectó en muestras congeladas, pero mostró una mayor prevalencia (16,7\%) en muestras frescas. Ambas especies se detectaron en diferentes productos avícolas, siendo C. jejuni más prevalente $(53,3 \%)$ en las muestras de hígado. C. coli mostró mayor prevalencia en muestras de trozos de carne (10\%). En ambas especies también se observó la presencia de cinco genes de virulencia relacionados con la adhesión (Peb1, JlpA, CadF y CapA) y la invasión (CiaB).

Palabras clave: Campylobacter; Pollos de engorde; Control microbiológico; PCR.

\section{Introduction}

Among the pathogens involved in foodborne outbreaks related to chicken meat, Campylobacter spp. are the most prevalent (Camino et al., 2017; Gourley et al., 2017). Campylobacter spp. infection, known as campylobacteriosis, is a worldwide zoonosis of serious public health concern, causing gastroenteritis in humans. Consumption of badly cooked poultry meat is one of the main risk factors associated with infection (Freitas and Noronha, 2007; Sharma et al., 2016).

Worldwide, Campylobacter spp. are among the main pathogens causing bacterial gastroenteritis (Li et al., 2018). They are gram-negative, microaerophilic bacteria with respiratory metabolism (Gorman and Adley, 2004; Wainwright et al., 2005). Campylobacter jejuni and Campylobacter coli have long been the most common species associated with cases of campylobacteriosis and other bacteremic infections (Iraola et al., 2014; Maziero and Oliveira, 2010). The Campylobacter infectious dose is approximately 500 colony-forming units/g, subject to the individual's physical condition or age (Granić et al., 2009). The infection is caused by virulence mechanisms involved in the production of toxins, motility flagella, adhesion, and epithelial invasion (Modi et al., 2015).

Worldwide, different health and food safety bodies, including the World Health Organization (WHO) and the United Nations Food and Agriculture Organization (FAO), have reported campylobacteriosis as the most prevalent foodborne disease, with rates higher than those reported for salmonellosis and shigellosis (Platts-Mills et al., 2014; WHO, 2013). Thus, a burden has been placed on both the food sector, owing to the need for monitoring and analyzing meat products to maintain the standard of food safety, and on public health, in terms of the costs of diagnosis and treatment (Naravaneni and Jamil, 2005).

In Brazil, research on Campylobacter is limited compared to developed and developing countries; however, over the years, studies conducted in different regions of Brazil have shown varying rates of Campylobacter prevalence, between $11 \%$ and 98\% (Franchin et al., 2007; Kuana et al., 2008; Azeredo et al., 2010; Carvalho et al., 2013; Feistel et al., 2012; Silva, 
2016). Although campylobacteriosis is classified as a foodborne disease and there is a specific information system for the investigation and notification of outbreaks and diseases, there is no specific Brazilian legislation for the control of Campylobacter (Brasil, 2010). This lack of control regarding the contamination of chicken meat by Campylobacter can compromise the food security of chicken meat considering that it is one of the most consumed meat products in Brazil and worldwide. In this study, we report the detection of Campylobacter spp. and virulence genes in chicken carcasses sold in different commercial establishments in a municipality in the northeast region of Brazil.

\section{Methodology}

\subsection{Sample Location and Collection}

Samples of broiler carcasses were acquired in two types of commercial establishments: three public markets and three supermarkets in Sanitary District III in Recife-PE. The carcasses marketed in the establishments originated from municipalities in one of the states in Northeast Brazil.

The carcasses acquired in the public markets did not have any inspection seal (municipal, state, or federal), whereas those acquired in supermarkets had a Federal Inspection Seal (SIF). Ten samples of carcasses with livers and gizzards sold in fresh, chilled, and frozen forms were obtained from two different commercial brands, totaling 90 samples.

Samples were transported in isothermal boxes $\left(2-8^{\circ} \mathrm{C}\right)$ with recyclable ice to the Meat and Derived Products Inspection Laboratory (LICPD) of the Department of Veterinary Medicine (DMV) of the Federal Rural University of Pernambuco (UFRPE).

Fresh and chilled samples of carcasses with livers and gizzards were processed upon arrival at the laboratory, whereas frozen samples were kept under refrigerated temperature for $24 \mathrm{~h}$ to promote thawing.

\subsection{Microbiological analysis of the samples}

Samples of chicken carcasses with livers and gizzards were analyzed following the guidelines of the International Organization for Standardization (ISO 10272-1) for the isolation and identification of Campylobacter spp. (ISO 2006).

The methodology provides for the enrichment of $25 \mathrm{~g}$ of sample in Bolton broth under microaerophilic conditions, with oven incubation at $37-42^{\circ} \mathrm{C}$ for $24-48 \mathrm{~h}$. In the present study, a 1:10 dilution was adopted, and from the $25 \mathrm{~g}$ portion (pieces and skin of the neck, breast, wing, cloacal region, livers, and gizzards), $10 \mathrm{~g}$ of sample was weighed, placed in a sterile stomacher bag, and $90 \mathrm{~mL}$ of Bolton Broth was added to the selective enrichment medium containing $5 \%$ (v/v) blood from lysed and defibrinated blood from the equine and selective supplement.

The stomacher bags, containing prepared samples and the selective enrichment medium, underwent a pre-enrichment stage under microaerophilic conditions at $37^{\circ} \mathrm{C}$ for $4 \mathrm{~h} \pm 1 \mathrm{~h}$ and an enrichment stage under the same conditions at $42^{\circ} \mathrm{C}$ for 48 h. After the enrichment period, each sample was homogenized and isolated on plates of modified charcoal cefoperazone agar deoxycholate (m-CCDA) and Campy Cefex, both supplemented with cefoperazone and amphotericin B. Samples were subsequently incubated under the same temperature conditions and period mentioned above.

Subsequently, colonies suspected of being Campylobacter, based on colony morphology for each medium used, were selected and replicated for new cultures on Columbia blood agar (CBA) supplemented with defibrinated sheep blood, following the same incubation pattern.

Colonies obtained from the plates were stored and frozen at $-20^{\circ} \mathrm{C}$ in Eppendorf microtubes containing ultrapure water for subsequent DNA extraction and confirmation of Campylobacter spp. by conventional PCR, while some were frozen under the same temperature conditions in microtubes containing $1 \mathrm{~mL}$ of brain-heart infusion broth (BHI) with $20 \%$ glycerol $(\mathrm{v} / \mathrm{v})$. 
All analyses were conducted in parallel with control strains of $C$. jejuni (ATCC 29428) and C. coli (CCAMP 1068).

\subsection{DNA extraction}

DNA was extracted from colonies obtained by cultivation and from the $15 \mathrm{~mL}$ aliquots of the enrichment broth, with the extraction process carried out in parallel with the microbiological analysis of the samples.

Genomic DNA was extracted from isolates via thermal extraction. Tubes were placed in a dry bath at $90^{\circ} \mathrm{C}$ for 15 $\mathrm{min}$, then in a freezer for $15 \mathrm{~min}$, followed by centrifugation for $5 \mathrm{~min}$ at $14000 \times \mathrm{g}$. The supernatants were stored in a freezer at $-20^{\circ} \mathrm{C}$ and used as target DNA for PCR analysis.

The extraction process from the enrichment broth was performed using the commercial Wizzard ${ }^{\circledR}$ Genomic DNA Purification kit (Promega $\left.{ }^{\circledR}\right)$ according to the manufacturer's protocol. Samples were stored in a freezer at $-20^{\circ} \mathrm{C}$ until PCR analysis.

\subsection{Molecular identification of Campylobacter spp.}

Specific primers for $C$. jejuni and C. coli were used to confirm species from the isolates and enrichment broth (Table 1). PCR followed the methodology by Casaril (2010). Subsequently, $6 \mu \mathrm{L}$ of the amplified DNA products were transferred, to which $0.5 \mu \mathrm{L}$ of Bluegreen ${ }^{\circledR}$ and $1 \mu \mathrm{L}$ of $1.5 \%$ or $2 \%$ agarose buffer were added, along with a 100 bp Ladder ${ }^{\circledR}$ molecular weight marker, and submitted to electrophoresis, under ultraviolet light and photo-documented by the gel documentation system, following conditions established by the laboratory protocols for carrying out the tests.

Table 1. Primers used in PCR reactions to detect C. jejuni and C. coli.

\begin{tabular}{|c|c|c|c|}
\hline Primers $^{\mathrm{a}}$ & Sequence $\left(5^{\prime}-3^{\prime}\right)$ & Product & Reference \\
\hline mapA-F & AGTCCTGGTGGTTTGAAGC & $202 \mathrm{pb}$ & Casaril, 2010 \\
\hline mapA-R & CCGCATTAAAATTCACATCG & & \\
\hline CeuE-F & ATGAAAAAATCTTTAGTTTTTGCA & $889 \mathrm{pb}$ & Casaril, 2010 \\
\hline CeuE-R & ATTTTATTATTTGTAGCAGCG & & \\
\hline
\end{tabular}

\subsection{Molecular detection of virulence genes}

The detection of virulence genes was performed according to the methodologies recommended by the authors, using the following primer sequences: Peb1 (5'-GCAGAAGGTAAACTTGAGTCTATT-3') and (5'TTATAAACCCCATTTTTTCGCTA A-3') (Pei et al., 1993); JlpA (5'-CACAGGGAATCGACAGCATAGA-3') and (5'ACGCTCCGCCCATTAACATA-3') (Veras et al., 2016); CadF (5'-TTGAAGGTAATTTAGATATG-3') and (5'CTAATACCTAAAGTTGAAAC-3'); CiaB (5'-TCATGCGGTGGCATTAGAATGGG-3') and (5'AGGTCTAACTTCATCAACCCTTTGCCA-3') (Konkel et al., 1999); and CapA (5'GGATCCATGGGTGTAAATGTTCGTTC-3') and (5'-GTCGACTTACCAAAGATAATTAAAC TGAGC-3') (Ashgar et al., 2007).

The PCR consisted of a final volume of $12.5 \mu \mathrm{L}$, and all thermal profiles of each reaction had an initial stage of $15^{\prime}$ at $95^{\circ} \mathrm{C}$ and a final extension stage of $10^{\prime}$ at $72^{\circ} \mathrm{C}$. Strains of $C$. jejuni (ATCC 29428) and C. coli (CCAMP 1068) were used as positive controls; for the negative control, a compound from all the constituents of the reaction mix was used without the 
addition of DNA. The reactions of the amplified products were visualized following the same protocol used to confirm the species.

\section{Results and Discussion}

\subsection{Detection of $C$.jejuni and $C$. coli in chicken carcasses marketed according to the type of establishment}

All results presented were from samples from Sanitary District III in Recife-PE.

Results of the analyses using PCR to detect $C$. jejuni and $C$. coli in chicken carcasses sold in different types of commercial establishments are shown in Tables 2 and 3, respectively.

Table 2. Detection of $C$. jejuni and $C$. coli in chicken carcasses according to the type of establishment.

\begin{tabular}{lcll}
\hline Type of Establishment & Number of samples & C. jejuni & C. coli \\
\hline Market & 30 & $4(13,3 \%)$ & $5(16,7 \%)$ \\
\hline Supermarket & 60 & $22(36,7 \%)$ & $9(15,0 \%)$ \\
\hline Total & 90 & $26(28,8 \%)$ & $14(15,6 \%)$ \\
\hline
\end{tabular}

Source: Authors.

The present study showed a higher prevalence of $C$. jejuni than $C$. coli in chicken carcasses sold in commercial establishments. Various worldwide studies on the prevalence of Campylobacter in poultry products have indicated that $C$. jejuni is the main species involved in cases of campylobacteriosis in humans, with detection rates of up to 90\% (EFSA, 2019). In turn, C. coli is the second most prevalent species, with detection rates between 5\% and 10\% (CDC 2018).

Table 3. Use of PCR to detect $C$. jejuni and $C$. coli in chicken carcasses from public markets and supermarkets.

\begin{tabular}{cccc}
\hline Establishment & Number of samples & $\boldsymbol{C . j e j u n i}$ & $\boldsymbol{C . c o l i}$ \\
\hline Market 1 & 10 & 0 & $1(10,0 \%)$ \\
\hline Market 2 & 10 & $4(40,0 \%)$ & $3(30,0 \%)$ \\
\hline Market 3 & 10 & 0 & $1(10,0 \%)$ \\
\hline Total & 30 & & \\
\hline Supermarket 1 & 24 & $8(33,3 \%)$ & $5(20,8 \%)$ \\
\hline Supermarket 2 & 24 & $8(33,3 \%)$ & $3(4,2 \%)$ \\
\hline Supermarket 3 & 12 & $5(41,7 \%)$ & \\
\hline Total & 60 & & \\
\hline
\end{tabular}

Source: Authors.

Regarding the presence of the two species based on the commercial establishment, $C$. coli was more prevalent than $C$. jejuni in samples from public markets. A large number of studies have shown a higher prevalence of $C$. jejuni than C. coli in chicken carcasses (EFSA, 2019); however, it is important to mention that, depending on the material sampled, the origin of the samples, and storage conditions, the rates of detection can vary considerably (Melo et al., 2013).

C. coli is more susceptible to refrigeration or freezing storage conditions than C. jejuni (Suzuky and Yamamoto, 2009; Wei et al., 2016); therefore, it is suggested that the higher positivity of $C$. coli in this study was associated with the sale of 
carcasses at room temperature.

The higher occurrence of $C$. coli concerning to $C$. jejuni in public markets can be associated with two factors: origin and health status of the lots, and temperature of the commercialization process. According to Wegener (2010), in some regions of cities, products from bird flocks with lower sanitary status than those from flocks sold in supermarkets are commonly supplied; the public establishments in this study were in such peripheral regions. Regarding the temperature factor, in harvesting places, the sale of carcasses at room temperature was predominant, a factor favoring the growth of $C$. coli, whereas even $C$. jejuni growing at room temperature had better resistance to the storage conditions employed (CDC, 2014).

In supermarket samples, $C$. jejuni had higher detection rates than $C$. coli. $C$. jejuni has been reported to be the most prevalent species (EFSA, 2019; Kudirkiene et al., 2013; Praakle-Amin et al., 2007), consistent with the results in this study. It is worth mentioning that even though there is a difference between the percentages of positivity between species, one of the most important factors that imply high prevalence rates is the contamination of chicken carcasses by Campylobacter.

\subsection{Detection of $\boldsymbol{C}$. jejuni and $\boldsymbol{C}$. coli in fresh, chilled, and frozen chicken carcass samples}

The results of the analyses using the PCR technique to detect $C$. jejuni and C. coli in fresh, chilled, and frozen chicken carcass samples and types of chicken carcass samples (pieces), livers, and gizzards are presented in Tables 4 and 5.

Table 4. Results of the detection of $C$. jejuni and $C$. coli in fresh, frozen, and frozen chicken carcasses.

\begin{tabular}{cccc}
\hline Samples & Number & $\boldsymbol{C}$. jejuni & $\boldsymbol{C . c o l i}$ \\
\hline Fresh & 30 & $4(13,3 \%)$ & $5(16,7 \%)$ \\
\hline Cold & 30 & $13(43,3 \%)$ & $4(13,3 \%)$ \\
\hline Frozen & 30 & $9(30,0 \%)$ & 0 \\
\hline Total & 90 & & \\
\hline
\end{tabular}

Source: Authors.

The profile of the occurrence of $C$. jejuni in different forms of the samples showed the highest detection rate in chilled carcasses, followed by frozen carcasses, with the lowest rate in fresh carcasses, thus, demonstrating the viability of $C$. jejuni under three different commercialization processes. According to Sampers et al. (2010) and CDC (2014), the storage temperature of the carcasses reduces the final counts of Campylobacter in chicken meat, which may explain the decrease in detection rates between the chilled and frozen carcasses as the treatment applied in frozen carcasses is more intense.

By comparing the detection rates of $C$. jejuni between samples subjected to heat treatment (cooling and freezing) and carcasses kept at room temperature, a lower detection rate was found in fresh samples, even though the latter were in favorable conditions for the multiplication of the bacteria. Lee et al. (1998) pointed to the ability of Campylobacter to replicate at $4^{\circ} \mathrm{C}$ and room temperature, which justified the higher detection rate of $C$. jejuni in chilled samples.

According to Birk et al. (2004), chicken meat is composed of protective compounds such as peptides and lipids, which prolong the viability of $C$. jejuni during storage. The use of cooling further enhances this characteristic, which may explain the higher percentage of detection obtained for chilled carcasses in this study.

There was a reduction in the detection rate of $C$. jejuni in frozen carcasses when compared to that of chilled carcasses. According to ISO (2006), Campylobacter spp. are highly sensitive to freezing; however, owing to their ability to assume a viable but non-cultivable form (VNC), they can remain in food as a sign of favorable conditions. As the enrichment broth was 
used in this study in processing the samples to recover cells, it is believed that the cells of the microorganisms present in the frozen carcasses were greatly stimulated by the conditions provided, favoring their detection.

It is important to note that the higher or lower detection rate in frozen carcasses may be associated with the origin and health status of chicken batches. In Denmark, Wegener (2010) found that chicken flocks positive for Campylobacter were generally used in the production of frozen birds, one of the forms of control of Campylobacter used in the country. In Brazil, unlike what occurs in other countries, the control of Campylobacter is not carried out, showing that birds of positive flocks can reach the consumer market through the three different forms of commercialization.

The type of slaughter used can be a compromising factor concerning greater or lesser contamination of carcasses. In this study, less contamination with $C$. jejuni was found in fresh carcasses than in chilled and frozen samples. This could be explained by the manual slaughter used in public markets to obtain fresh carcasses. In addition, a smaller number of birds are slaughtered in public markets than that for chilled and frozen carcasses that pass through the slaughter platform, thus, potentially favoring contamination by Campylobacter for the time that the carcasses spend in the slaughter line (Wei et al., 2016).

The profile of the occurrence of $C$. coli in the three commercialization processes occurred in a descending manner, with a detection rate of $16.7 \%$ in fresh samples. There was a percentage reduction to $13.3 \%$ in positive samples of carcasses subjected to cooling, with no detection in carcasses where freezing was employed, showing the inherent sensitivity of $C$. coli to the thermal stress generated by the use of conservation methods. Corroborating with observations similar to the present study, Maziero and Oliveira (2010) evaluated the same quantity of frozen samples and did not obtain positivity for C. coli.

Abd El-Aziz and Abd-Allah (2017) obtained superior results when assessing the presence of $C$. coli in fresh carcasses, with $87.5 \%$ of the samples positive. In their study, Igwaran and Okoh (2020) evaluated the presence of different species of Campylobacter in different types of chilled meat at retail and slaughterhouses, including chicken meat, and obtained a prevalence rate of $22.08 \%$ for C. coli.

Table 5. Results of the detection of $C$. jejuni and C. coli in carcasses of chicken, liver, and gizzards.

\begin{tabular}{cccc}
\hline Samples & Number & $\boldsymbol{C}$. jejuni & $\boldsymbol{C}$. coli \\
\hline Pieces & 30 & $11(36,7 \%)$ & $3(10 \%)$ \\
\hline Liver & 30 & $16(53,3 \%)$ & $1(3,3 \%)$ \\
\hline Gizzard & 30 & $10(33,3 \%)$ & $1(3,3 \%)$ \\
\hline Total & 90 & & \\
\hline
\end{tabular}

Source: Authors.

The prevalence of $C$. jejuni in the samples of meat pieces was $36.7 \%$, the second-highest percentage among the different types of meat (beef, pork, and sheep). Most of the studies that searched for Campylobacter spp. in chicken carcasses, whether whole or in pieces of carcasses, use the rinsing methodology or cut pieces. According to Hansson et al. (2014), the presence of skin in the samples greatly influences the achievement of positive results. Similarly, Sampers et al. (2010) observed a high incidence of bacteria when analyzing meat preparations with skin. The exposed data corroborated the prevalence found in this study, as the fragments of carcasses collected to compose the samples of meat pieces were collected with skin.

Among the different samples, $C$. jejuni occurred in more than half of the liver samples, followed by considerable percentages for the samples of meat pieces and gizzards. Detection rates for C. jejuni and C. coli species in chicken liver vary 
from 10\% to $90 \%$ (Chaloner et al., 2014; Firlieyanti et al., 2016; Whyte et al., 2006).

In gizzard samples, the detection rate of $C$. jejuni was $33.3 \%$ positive. Boufleur (2009) obtained a prevalence of 44.4\% positive samples, a higher percentage than the present study. A higher prevalence was also verified by Trassi (2012), who analyzed samples of gizzards from slaughterhouses, obtaining 50.0\% positivity. A lower percentage of $C$. jejuni than that in this study was verified by Chaves et al. (2010), who analyzed the same quantity of gizzards and obtained only $3.3 \%$ of positive samples for $C$. jejuni. The same percentage (3.3\%) found for $C$. jejuni by the author was also found for $C$. coli.

Gutting has been identified as a critical point for contamination in the slaughter of carcasses and chicken products (liver and gizzards) (Rosenquist, 2006). Once contaminated, the products pass through the slaughter flow and are sent to the market. Research also points to the long-term survival of Campylobacter for long periods in retailed chicken products (Birk et al., 2006; El-Shibiny et al., 2009; Solow et al., 2003). This explains the reported outbreaks associated with the consumption of this food type (Glashower et al., 2017; Hanson et al., 2014; Scott et al., 2015; Tompkins et al., 2013).

The prevalence of $C$. coli in the three different products was considerably lower than that in $C$. jejuni, with detection rates of $10.0 \%$ for lump samples and $3.3 \%$ for livers and gizzards. The detection of the highest prevalence of the species in samples of meat pieces further confirmed that the presence of skin in the samples favored the detection of the bacteria. The lower percentage of positivity could also be associated with the low population of microorganisms in different samples and their fastidious nature (Vandamme, 2000), slowing the growth of Campylobacter, which suffers the action of competing microbiota. Thus, it is suggested that the growth of competing microbiota is different from that of Campylobacter and that when using detection techniques, in this case, PCR the amount of target DNA of the species in question does not present detectable levels in the reaction.

\subsection{Detection of virulence genes in positive samples for $C$. jejuni and $C$. coli}

The results obtained from the analyses using the PCR technique to detect the virulence genes Peb1, JlpA, CadF, $C i a \mathrm{~B}$, and CapA of the 26 positive samples for $C$. jejuni and 14 for $C$. coli are described in Table 6.

Table 6. Detection of virulence genes in positive samples for $C$. jejuni and C. coli.

\begin{tabular}{rcc}
\hline Virulence genes & C. jejuni & C. coli \\
\hline Peb1 & $13(43,2 \%)$ & $7(50 \%)$ \\
\hline$J l p \mathrm{~A}$ & $18(48,6 \%)$ & $6(42,8 \%)$ \\
\hline CadF & $27(72,9 \%)$ & $7(50 \%)$ \\
\hline CiaB & $26(70,2 \%)$ & $10(71,4 \%)$ \\
\hline CapA & $8(21,6 \%)$ & $4(28,5 \%)$
\end{tabular}

Source: Authors.

The virulence genes studied are associated with the virulence of Campylobacter spp. and encode proteins involved in adhesion, invasion, and colonization. The presence of each of these genes suggested a biological and potentially pathogenic action involved in Campylobacter infection, and the mechanism by which they cause diseases in humans is multifactorial (Chukwu et al., 2019; Silva et al., 2011).

In the molecular analysis of the presence of five virulence genes for C. jejuni and C. coli, CiaB and CadF genes showed remarkable detection rates. These genes are associated with the invasion and colonization of host intestinal cells (Cróinín et al., 2012; Wieczorek et al., 2012). Different studies have reported the absence of the CiaB gene when analyzing 
samples of chicken meat, at retail positive for C. jejuni and C. coli (Igwaran and Okoh, 2020), to 100\% prevalence in stool samples from children with diarrhea positive for $C$. jejuni (Ghorbanalizadgan et al., 2014). For the CadF gene, there are reports of $100.0 \%$ prevalence of the gene for both species (Biswas et al., 2011; Ghunaim et al., 2015; Koolman et al., 2015).

Another gene detected was the Peb1 gene, which encodes the protein Peb1, an adhesin located in the periplasm, whose function is related to adhesion to host cells (Pei et al., 1998). The prevalence was $43.2 \%$ and $50.0 \%$ in $C$. jejuni and $C$. coli samples, respectively. Kim et al. (2019) reported detection rates of the gene in chicken meat samples at retail positive for C. jejuni $(93.3 \%)$ but did not include C. coli in the study.

The prevalence of the JlpA gene in C. jejuni and C. coli samples was similar, with $48.6 \%$ and $42.8 \%$ positivity, respectively. There are reports of detection of the gene with the detection range between $43.1 \%$ and $96.1 \%$ (Biswas et al., 2011; Koolman et al., 2015; Veras et al., 2016); however, these studies were performed only with samples positive for $C$. jejuni. In the present study, the JlpA gene was detected in both $C$. jejuni and C. coli, with similar percentages, noting that most studies researched the expression of this and other genes only in the species C. jejuni. The JlpA gene is responsible for the secretion of lipoproteins that act as adhesins, linking microorganisms to epithelial cells (Jin et al., 2001).

The lowest detection rate was for CapA, with $21.6 \%$ and $28.5 \%$ for C. jejuni and C. coli, respectively. This gene also encodes proteins related to adhesion to epithelial cells and acts as a cell colonization factor (Ashgar et al., 2007).

\subsection{Description of virulence profiles for $C$. jejuni and $C$. coli species}

Description of virulence profiles of the 26 C. jejuni and 14 C. coli samples are presented in Table 7.

Table 7. Virulence profiles concerning the genes detected in the species $C$. jejuni and $C$. coli.

\begin{tabular}{|c|c|c|}
\hline Virulence profile & C.jejuni & C. coli \\
\hline P-1: Peb1, JlpA, CadF, CiaB,CapA & $0(0 \%)$ & $1(7,1 \%)$ \\
\hline P-2: Peb1, JlpA, CadF, CiaB & $4(15,3 \%)$ & $2(14,2 \%)$ \\
\hline P-3: Peb1, JlpA, CadF & $0(0 \%)$ & $1(7,1 \%)$ \\
\hline P-4: Peb1, JlpA, CiaB & $3(11,55 \%)$ & $0(0 \%)$ \\
\hline P-5: Peb1, CadF, CiaB & $1(3,8 \%)$ & $1(7,1 \%)$ \\
\hline P-6: Peb1, CadF & $2(7,6 \%)$ & $1(7,1 \%)$ \\
\hline P-7: Peb1, CiaB & $1(3,8 \%)$ & $1(7,1 \%)$ \\
\hline P-8: Peb1, CapA & $0(\%)$ & $0(0 \%)$ \\
\hline P- 9: Pebl & $0(0 \%)$ & $1(7,1 \%)$ \\
\hline P-10: JlpA, CadF, CiaB, CapA & $1(3,8 \%)$ & $1(7,1 \%)$ \\
\hline $\mathrm{P}-11: J l p \mathrm{~A}, C a d \mathrm{~F}$ & $1(3,8 \%)$ & $0(0 \%)$ \\
\hline $\mathrm{P}-12: J l p \mathrm{~A}, C a d \mathrm{~F}, C i a \mathrm{~B}$ & $0(0 \%)$ & $0(0 \%)$ \\
\hline P-13: JlpA, CiaB, CapA & $0(0 \%)$ & $2(14,2 \%)$ \\
\hline P-14: JlpA, CapA & $0(0 \%)$ & $1(7,1 \%)$ \\
\hline
\end{tabular}




\begin{tabular}{ccc}
\hline P-15: $C a d F, C i a B$ & $1(3,8 \%)$ & $2(14,2 \%)$ \\
\hline P-16: CadF, CiaB, CapA & $0(0 \%)$ & $0(0 \%)$ \\
\hline P-17: CadF & $2(7,6 \%)$ & $0(0 \%)$ \\
\hline P-18: $C i a \mathrm{~B}$, CapA & $1(3,8 \%)$ & $1(7,1 \%)$ \\
\hline P-19: $C i a \mathrm{~B}$ & $2(7,6 \%)$ & $0(0 \%)$ \\
\hline P-20: Absence of all genes & $2(7,6 \%)$ & $2(14,2 \%)$ \\
\hline
\end{tabular}

Source: Authors.

From gene detection, 20 virulence profiles were constructed for each species. The constructed profiles contained everything from the presence of the five genes to the absence of all of them.

The P-1 profile ( $P e b 1, J l p \mathrm{~A}, C a d \mathrm{~F}, C i a \mathrm{~B}, C a p \mathrm{~A})$ is noteworthy for grouping the five genes, although it was detected only in $C$. coli samples and was absent in $C$. jejuni samples. This profile showed a variation in the expression of virulence factors between $C$. jejuni and $C$. coli. It is worth mentioning that there is no description in the literature on the detection of the gene profiles described in this study, which is important to study because, as these genes are associated with the ability of the cells to adhere to and colonize the host (Silva et al., 2011).

The P-2 profile (Peb1, JlpA, CadF, CiaB) was the second most prevalent, and unlike the P-1 profile, it occurred in both species, with the presence of four of the studied genes being verified. The presence of these genes gives species the ability to adhere and colonize host cells (Veras et al., 2016).

There was variation in other profiles for their detection for both species. However, it is worth mentioning the presence of the profiles P-5 (Peb1,CadF, CiaB), P-6, P-7 (Peb1,CiaB), P-10 (JlpA,CadF, CiaB,CapA), P-15 (CadF, CiaB), and P-18 $($ CiaB, CapA), all of which, even with different detection rates between species, were detected in both $C$. jejuni and $C$. coli samples. Additionally, in all profiles, there was the presence of the $\mathrm{CiaB}$ gene and in four of them the presence of the $\mathrm{CadF}$ gene, thus signaling that their expression by the species is a mechanism that gives it marked virulence.

The absence of the five genes was represented by the P-20 profile expressed for both species. Even in the absence of the detected genes, it was not possible to state that the species are not virulent, considering the diversity of other virulence genes that exist and that may confer an even greater capacity than those of the present study.

In recent years, Campylobacter spp. has been recognized an emerging pathogen and indicator of gastroenteritis worldwide. The main risks associated with infections by this pathogen are contaminated chicken carcasses in slaughterhouses, post-slaughter treatments, temperature control, and hygiene management during processing or storage (Rozynek et al., 2005; Stern et al., 2001). The combination of these factors associated with the presence of Campylobacter spp. with different virulence profiles detected warns of the potential risk for humans in the appearance of cases and/or outbreaks of Campylobacter infections if appropriate measures are not implemented.

\section{Conclusion}

C. jejuni and C. coli occur in different poultry products (carcasses, livers, and gizzards) sold in different establishments in northeastern Brazil, with $C$. jejuni being the most prevalent species.

The study revealed that even with the use of cooling and freezing in food, it was possible to recover Campylobacter, demonstrating that the methods act as a limiter, but do not eliminate the bacteria from the product. 
The PCR assay proved to be a suitable method for detecting virulence gene species.

The presence of virulence genes played a role in the ability of $C$. jejuni and $C$. coli to remain viable in food.

There should be continued surveillance for the presence of these pathogens and their genes associated with poultry products. Control measures must be established from the field to the industry. The use of agents such as bacteriophages and probiotics is a promising alternative in the biocontrol of foodborne pathogens such as Campylobacter at the field level. In terms of industry, strengthening the monitoring of handling measures and practices during processing continues to be essential to reduce the contamination of poultry products and the probable risk of infection. Additionally, awareness-raising measures must be taken on the risks associated with the consumption of undercooked meat and on the care that the consumer must take in handling these food products to avoid possible cross-contamination, to preserve their food safety.

\section{Acknowledgments}

We would like to thank the Coordination for the Improvement of Higher Education Personnel (CAPES) for the granting of a Master's scholarship. We would also like to thank the Campylobacter Sector of the Laboratory of Bacterial Zoonoses (LABZOO) of the Oswaldo Cruz Foundation (Fiocruz - RJ) for their assistance in sending the standard strains from the Campylobacter Collection (CCAMP).

\section{References}

Alves, J. M. C. S. \& Oliveira, T. C. R. M. (2013). Presença de Campylobacter spp. em cortes refrigerados de frango. Semina: Ciências Agrárias, Londrina, v. 34(6), pp. 2829-2836. DOI: 10.5433/1679-0359.2013v34n6p2829.

Aquino, M. H. C., Pacheco, A. P. G., Ferreira, M. C. S. \& Tibana. A. (2002). Frequency of isolation and identification of thermophilic Campylobacters from animals in Brazil. The Veterinary Journal, v.164(2), pp.159-165. DOI:10.1053/tvj1.2001.0698.

Azeredo, L. I.; Luchese, R. H. \& Lauria-Filgueira, A. L. (2010). Campylobacter spp em carne de ave crua: avaliação da etapa de resfriamento. Revista Instituto Adolfo Lutz., v. 69(4), pp.518-524.

Bhunia, A. K. (2008). Foodborne microbial pathogens: mechanisms and pathogenesis. Purdue University, pp. 217-225. DOI: 10.1007 / 978-0-387-74537-4.

Boufleur, R. (2009). Campylobacter Jejuni em frango de corte, carne e vísceras de frango no Rio Grande Do Sul e efeito do congelamento sobre a contaminação nos cortes. Dissertação (Mestrado Em Medicina Veterinária) - Universidade Federal de Santa Maria - UFSM. Santa Maria.

Butzler, J.P. (2004). Campylobacter, From obscurity to celebrity. Clinical Microbiology And Infection, v.10(10), pp.868-876. DOI: 10.1111/j.14690691.2004.00983.x.

CDC - Centers For Disease Control And Prevention. (2012). Campylobacter Investigation Guideline. Kansas Disease Investigation Guidelines. Atlanta: Georgia.

CDC - Centers for Disease Control and Prevention. (2018). Campylobacter Investigation Guideline. Kansas Disease Investigation Guidelines. Version 05/2018. Atlanta: Georgia.

Cortez, A. L. L. (2003). Indicadores de qualidade higiênico-sanitária em linguiça frescal comercializada no município de Jaboticabal-SP. Dissertação De Mestrado, Universidade Estadual Paulista, Faculdade De Ciências Agrárias E Veterinárias, Jaboticabal.

Cortez A. L. L., Carvalho A. C. B. F., Scarcelli, L., Miashiro, S., Vidalmartins A. M. C. \& Burger K. P. (2006). Survey of a chicken abattoir for the presence of Campylobacter jejuni and Campylobacter coli. Rev Inst Med Trop S Paulo. 48(6), pp. 307-310. DOI: 10.1590 / s0036-46652006000600001.

Costa, C. A. R. (2010). Avaliação da exposição do consumidor à Listeria monocytogenes, Salmonella spp., Campylobacter spp. e Escherichia Coli Produtora de toxina de shiga em produtos cárneos refrigerados comercializados no município de São Paulo. Tese (Doutorado) - Faculdade De Ciências Farmacêuticas, Universidade De São Paulo, São Paulo.

Cróinín, T. Ó. \& Steffen, B. (2012). Host epithelial cell invasion by Campylobacter jejuni: trigger or zipper mechanism?. Front. Cell. Infect. Microbiol. v. 2(25) pp. 1-13. DOI: 10.3389/fcimb.2012.00025.

EFSA and ECDC (European Food Safety Authority And European Centre For Disease Prevention And Control). (2018). The European Union Summary Report On Trends And Sources Of Zoonoses, Zoonotic Agents And FoodBorne Outbreaks In 2017 .URL <https://efsa.onlinelibrary.wiley.com/DOI/epdf/10.2903/j.efsa.2018.5500 >.

EFSA (European Food Safety Authority) (2019). Scientific report on the European Union one health 2018 zoonoses report. EFSA Journal. URL: <https://DOI.org/10. 2903/j.efsa.2019.5926>. 
Eucker, T. P. \& Konkel, M. E. (2012). The cooperative action of bacterial fibronectin-binding proteins and secreted proteins promote maximal Campylobacter jejuni invasion of host cells by stimulating membrane ruffling. Cellular Microbiology v.14(2), pp. 226-238. DOI: 10.1111 / j.1462-5822.2011.01714.x.

FAO/WHO- Food and Agriculture Organization of The United Nations/World Health Organization. (2009). Salmonella and Campylobacter In Chicken Meat: Meeting. Microbiological Risk Assessment Series n. 19. Rome, Italy.

Feistel, J. C., Sola, M. C., Medeiros, N. X., Trassi, A. M. C., Mesquita, S. Q. P., Silva Junior, M. C. \& Rezende, C. S. M. D. E. (2012). Identificação e biotipificação de cepas de Campylobacter spp. isoladas de produtos avícolas. Anais Do Congresso De Pesquisa, Ensino e Extensão - Conpeex (2012). Anais.

Fitzgerald, C., Helsel, L. O. \& Nicholson, M. A. (2001). Evaluation of methods for subtyping Campylobacter jejuni during an outbreak involving a food handler. J. Clin. Microbiol., v.39(7), pp. 2386-2390. DOI: 10.1128\%2FJCM.39.7.2386-2390.2001.

Forsythe, S. J. (2000). Na Microbiologia Do Alimento Seguro. Microrganismos De Intoxicação Alimentar. $1^{\text {a }}$ Ed. pp. 87-148. Porto Alegre: Abingdon: Editores Da Blackwell Science.

Franchin, P. R., Aidoo, K. E. \& Batista, C. R. V. (2005). Sources of poultry meat contamination with thermophilic Campylobacter before slaughter. Brazilian Journal Microbiology, v.36(2), pp.157-162. DOI: 10.1590/S1517-83822005000200011.

Franco, B. D. G. M. \& Landgraf, M. (2005). Microbiologia Dos Alimentos. Atheneu.: São Paulo.

Frazier, W. C.; Westhoff, D. C. (1993). Microbiologia De Los Alimentos, $4^{\circ}$ Edição, Editora Acribia, Zaragoza.

Freitas, J. A. \& Noronha, G.N. (2007). Ocorrência de Campylobacter Spp. em carne e miúdos de frango expostos ao consumo em Belém, Pará. Arquivo Brasileiro De Medicina Veterinária E Zootecnia, v.59(3), pp. 813-815. DOI: 10.1590/S0102-09352007000300038.

Gorman, R. \& Adley, C. C. (2004). An evaluation of five preservation techniques and conventional freezing temperatures of $-20^{\circ} \mathrm{c}$ and $-85^{\circ} \mathrm{c}$ for long-term preservation of Campylobacter jejuni. Letters Applied Microbiology_v. 38(4), pp.306-10.

Invitrogen. Real-Time Pcr: From Theory To Practice - Handbook. (2008). 72f.

Jasson, V., Sampers, I., Botteldoorn, N., López-Gálvez, F., Baert, L., Denayer, S., Rajkovic, A., Habib, I., De Zutter, L., Debevere, J. \& Uyttendaele, M. (2009). Characterization Of Escherichia coli from raw poultry in Belgium and impact on the detection of Campylobacter jejuni using Bolton broth. International Journal Of Food Microbiology, v. 135(3) pp. 248-253. DOI: 10.1016/j.ijfoodmicro.2009.09.007.

Maziero, M. T. \& Oliveira, T. C. R. M. (2010). Effect of refrigeration and frozen storage on the Campylobacter Jejuni recovery from naturally contaminated broiler carcasses. Brazilian Journal Of Microbiology, v. 41(2), pp. 501-505. DOI: 10.1590/S1517-83822010000200034.

Medeiros, V. M. (2011). Isolamento e identificação fenotípica e molecular das espécies termofílicas de Campylobacter a partir de frango resfriado. (Dissertação De Mestrado Profissional). Fundação Oswaldo Cruz. Instituto Nacional De Controle De Qualidade Em Saúde, Programa De Pós-Graduação Em Vigilância Sanitária, Rio De Janeiro-RJ.

Medeiros V. M., Bricio S. M. L., Filgueiras A. L. L. \& Clementino M. B. M. (2012). utilização de caldo Bolton no enriquecimento seletivo em comparação ao plaqueamento direto na pesquisa de Campylobacter spp. em carcaças resfriadas de frango. Revista Do Instituto Adolfo Lutz.v.71(3), pp.456-461. DOI: $10.98552012000300004 \& \operatorname{lng}=$ es\&tlng=es.

Moura Filho L. G. M., Bezerra S. S., Barros G. C., Melo H. M. G., \& Mendes E. S. (2010). Perfil microbiológico da carne de frangos abatidos artesanalmente e na indústria, comercializados na grande Recife-PE. Medicina Veterinária, v.4(1) pp.12-17.

Mulinari, E. L., Salvatori R. U. \& Majolo, C. (2014). Enumeração de Campylobacter em carcaças, cortes e miúdos de frango produzidos no rio grande do sul. Caderno Pedagógico. v.11(1), pp. 91-98. DOI: 10.22410/issn.1983-0882.

Nachamkin I, Szymanski C. M. \& Blaser M. J. (2008). Campylobacter, 3 Ed. Emerging Infectious Diseases. Asm, Washington.

Notermans, S. \& Hoogenboom-Vedergaal, A. (1992). Existing and emerging foodborne diseases. International Journal Of Food Microbiology, v. 15(3), pp. 197-205. DOI: 10.1016 / 0168-1605 (92) 90049-9.

Rozynek, E., Dzierzanowska-Frangat, K., Jozwiak, P., Popowski, J., Korsak, D. \& Dzierzanowska, D. (2005). Prevalence of potential virulence markers in Polish Campylobacter jejuni and Campylobacter coli isolates obtained from hospitalized children and from chicken carcasses. Journal Med. Microbiol., v.54(7), pp. 615-619. DOI: 10.1099 / jmm.0.45988-0.

Santos, E. L. S. (2016). Detecção E Identificação De Campylobacter Spp. Em Carcaças De Frango De Corte Produzidas No Estado De Minas Gerais. (Dissertação De Mestrado). Universidade Federal De Minas Gerais, Belo Horizonte-MG.

Stern, N. J., Line, J. E. \& Chen, H. C. (2001). Campylobacter In: Downes, F. P.; Ito, K. Chapter 31. Compendium Of Methods For The Microbiological Examination Of Foods, pp. (301-310). Washington, Dc: Apha.

Vandamme, P. (2000). Taxonomy Of The Family Campylobacteraceae. Campylobacter, 2 Ed. pp. (3-44). Washington.

Wieczorek, K., Denis, E., Lynch, O. \& Osek, J. (2013). Molecular characterization and antibiotic resistance profiling of Campylobacter isolated from cattle in Polish slaughterhouses. Food Microbiology. v.34(1), pp. 130- 136. DOI: 10.1016 / j.fm.2012.12.003. 